\title{
Information system to enhance medical services quality in Indonesia
}

\author{
Susana Limanto, Andre \\ Engineering Faculty, Department of Informatics, University of Surabaya, Indonesia
}

\begin{tabular}{l}
\hline \hline Article Info \\
\hline Article history: \\
Received Aug 8, 2018 \\
Revised Nov 23, 2018 \\
Accepted Dec 20, 2018 \\
\hline
\end{tabular}

\section{Keywords:}

Information system

Medical record

Medical service

Queue management

\begin{abstract}
The consequence of disproportionate distribution and placement of Doctor in Indonesia is affecting people who live in rural area. Patient have to travel to city to receive medical treatment and must encounter another different problem such as: patients often have to wait a long time in the doctor's office even sometimes do not get the service because of holiday or rejected because the queue is full. Medical record in some cases may lost due in Indonesia mostly medical record recorded manually (paper based). Therefore doctor treatment is not optimal because doctor can no longer inspect patient illness history and any treatment that have been conducted before. This research proposes a new concept to help people who live in rural area to get better medical treatment. People could register and monitor doctor service queue via smart phone. System expanded with medical record management facilities to improve service quality of patient. Research object was doctor service in Sulawesi, Indonesia. This research indicates system could increase time efficiency, energy, and cost efficiency for patient and also the doctor. Additionally current system will be optimal if supported with stable internet network.
\end{abstract}

Copyright $\odot 2019$ Institute of Advanced Engineering and Science. All rights reserved.

\section{Corresponding Author:}

Andre,

Department of Informatics,

University of Surabaya,

Raya Kalirungkut Road, Surabaya 60292, Indonesia.

Email: andre@staff.ubaya.ac.id

\section{INTRODUCTION}

Healthiness is important thing to humankind [1]. People will do everything to stay healthy. With healthy body people able to work on daily routine at maximum effectiveness [2]. If people feel unwell, their willingness to obtain proper medical examination and treatment also increased. People will do several things such as consuming medical/herbal medicine, consulting to doctor, and changing daily habit in order to maintain their healthiness level back to maximum [3]. In point of fact, people compliant to consulting doctor which clinic location relatively far from their home.

The number of doctor is not sufficient to satisfy medical service demand in Indonesia [4]. Additionally there are problem of disproportionate distribution and placement of doctor between city and rural area [5]-[7]. Uneven spread of doctors give significant effect on service effectiveness on certain area. People live on rural area must travel a far (to city) to receive medical service and in many cases they unable to obtain the service because several reason, for example full queue, and doctor take a leave. Those problems lead to inefficiency on time, cost, and effort [8].

Doctors rely on good and reliable medical records to provide treatment on patient. Data obtained from medical record could be reference and consideration for any future medical treatment. Most of clinic and dispensary in Indonesia stored patient medical record in form of paper based. These form and paper usually stored inside filing cabinet or cupboard. This method has several disadvantages, one of common 
problems rouse when searching patient medical record. It takes time to search patient medical record and if the data are lost (there are no backup for paper based data) then Doctor unable to provide proper and maximum medical treatment to patient. Doctor only obtains information from patient current conditions.

Based on current problems in Indonesia, one feasible solution is develop mobile based Medical Information System and Queuing Management System Services which never conducted on any previous research before in Indonesia. This research bring new concept for Indonesia people who lived on rural area to register and use queue monitoring system using their smartphone. Highlighted features include online registration, queuing management, and medical records. The object of research is dental care clinic in Sulawesi, Indonesia. This research projected to simplify patient registration and appointment, therefore patient aware queue number and able to planning time schedule to attend dentistry treatment on location. Furthermore online integrated medical records projected to assist Doctor in searching for particular patient dental health records and teeth structure visualizes could provide doctor with informative and well presented data about patient dental health. Doctor expected to delivering optimum medical treatment on patient prior using the Medical Services Information System.

\section{CURRENT RESEARCH}

Medical Information System already properly established in many countries, including Indonesia [9], [10]. It offers lucrative benefit such as increasing service availability and reliability to the patient and also diminishing expenditure [11]. Considerable research related to Medical Information System development are Personal Physician Practice Information System [12], Dental Clinic Information System [13], Obstetrics and gynecology Clinic Information System [14], Puskesmas Information System [15], Clinic Information System [16], [17], Hospital Medical Record Information System [18]-[20], Cloud Based Medical Record for Healthiness Industry [11] and Student Health Monitoring [21]. Information System of general practitioner services which developed by Taufik responsible to handle medical record management on patient, online or offline registration, queue number print service, and queue number announcement [12]. Web based information system used by dentist, gynecologist and obstetrician which developed to handles patient medical record and online registration [13], [14]. Sundari developed Puskesmas information system with several keys features which are: medical records management, online registration, and queue number print service that required when patient attend the doctor [15]. Polyclinic Information System developed by Faruq administers medical records for three services: general practitioner, dentist, and psychologist [17].

Research conducted by Marques to develop Hospital Information System that have ability to manage comprehensive patient care information such as medical records, appointments scheduling, theatre management and ward reporting [18]. Hospital Information System also developed by Cortes and Nguyen. Both administer patient medical records management [19], [20]. Additionally system also manages pharmaceutical, finance, and integrated automatically with USG, Radiography, CT Scan, MRI and laboratory (have automated data acquisition from Ultrasound, Digital Radiography, CT scanner, MRI and Laboratory stations, and manage pharmacy and financial information) [20]. All medical information system R\&D which mainly serves medical services such as medical record management does not provide facilities to supervise patient queue management even though some have online registration features. The outcomes of those researches indicate that Information System solution on medical environment granted beneficially effect especially increasing efficiency and services quality on patient. Furthermore, the conclusions from this research conjointly supported by other relevant research that deliberately related with information technology involvement in medical field. These researches propagating several noticeable results such as: proliferating employee compliance to regulation [22], increasing quality and efficiency [23], accelerating communication and integration between unit in the system [24], [25] and increasing quality and efficiency from hospital support and health employee in the form of enhancement of individual authority and training [26].

The survey outcome organized by APJII [27] indicates that internet user in Indonesia on 2016 have increased around 50\% compared with 2015. Most Internet users are on the island of Java, which is about 65\% of the total Internet users [27]. This number described clearly on Figure 1 [27]. Other sources stated that 9 of 10 internet users (93\%) accessing internet from smart phone [28]. The high number of smart phone users open the opportunity to utilizes smart phone as broadcasting tools [14] and mobile application development [29], [30]. Mobile application inherited distinctive characteristic that make it favorable and more personal. Several of those characteristics are: real time communication [25]; multi function, multi capability, not just for communication tools, mobile can access internet, searching through the networks, and executing installed application [31]. The latest researches of involvement mobile devices on medical field are pharmacy [31], [32], surgery [33], education and medical training [34], [35], and telemedicine [36]. The outcomes of those research indicates that mobile application can improve communication between hospital and patient 
comparing with web application [31], [37], maintaining patient loyalty [14], and increasing efficiency of services and lowering operational cost [35].

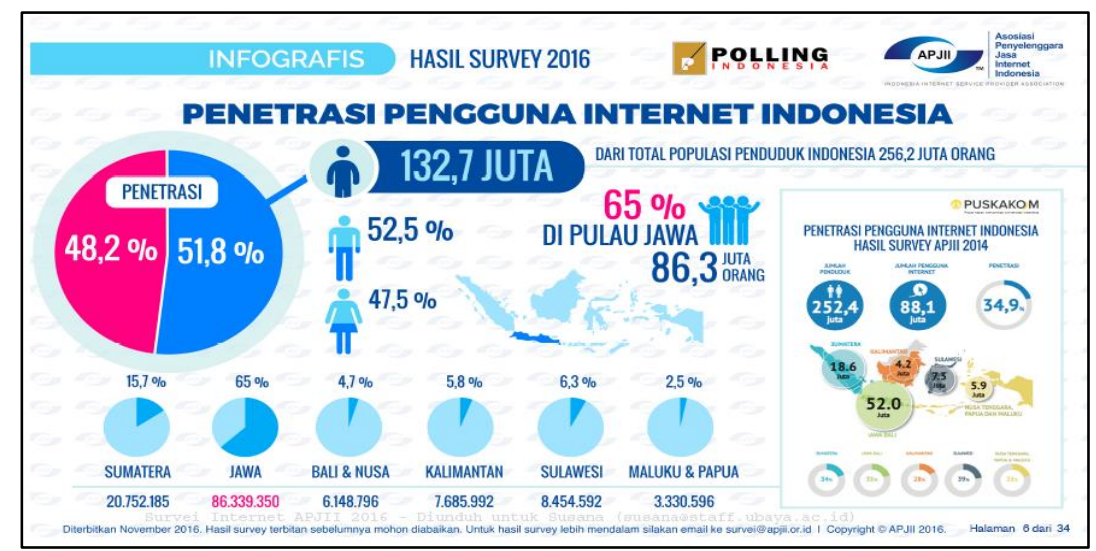

Figure 1. Indonesia internet users statistics

\section{RESEARCH METHOD}

Methods used to collect data are interview, observing ongoing system, and scrutinize related document. The interview was held with internal user (Doctor, assistant, and administrator officer) and several patient as external user. Data collected from patient using simple random sampling method, which is sample collected randomly among patient during doctor officer hour. Hereinafter data was analyzed to formulate the requirements from the user and preparing the application grand design as expected by internal and external user.

The outcomes of analysis were used to develop Medical Information System Services and Patient Queue Management. Before implementing the system, validation step is prerequisite in order to achieve high users satisfaction based on requirements. Validation method used was propagating questionnaire to ten random patients and interviewed Doctor as the object of research. Several suggestions and critics from respondents were used to refining the application.

Design of queue management system is shown in Figure 2. System was implemented on distributed environment which mean that several server deployed on different location based on real condition. There is separation between administrative process and user apps. For example Queue Application Server was deployed systematically within rural area boundary. Medical service request from patients will be added into the queue pool and system will publish queue number with important details such as estimated time served. The synchronize process between server occurred in real time, therefore patients immediately receive notification using Firebase Cloud Service. Thereafter, doctor serves patient according queue order and log the patient medical records using web based application and patient can monitor the queue using mobile phone.

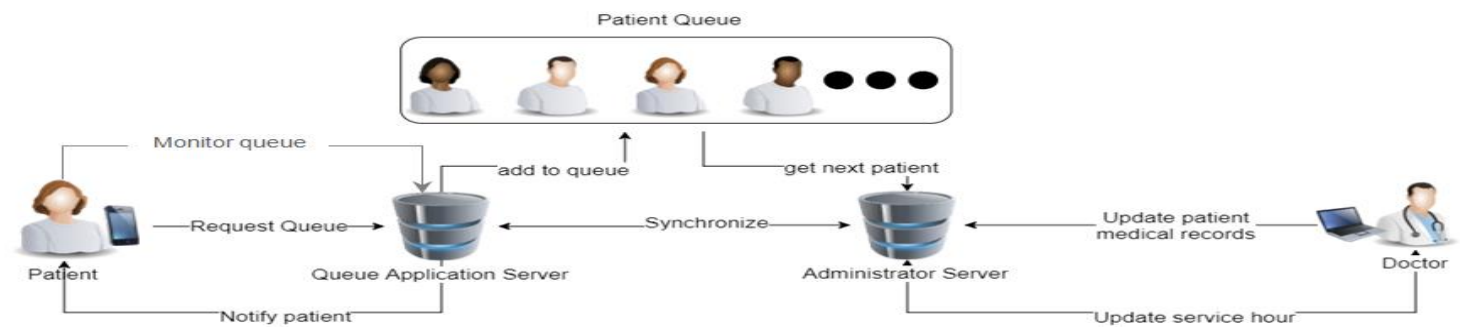

Figure 2. Queue system diagram

\section{RESULTS AND DISCUSSIONS}

Development are focusing on two parts specifically are internal use (administrator, clinic or Doctor) and patient. System requirement expected by internal use are: 
a. Initialization

System admin conduct set up on several initial configurations including: service hour, medical treatment data management, symptom data management, and time estimation per treatment.

b. Patients Data Management

This feature are assisting administration officer on registration and adjusting patient personal data.

c. Registration

Assisting administrator to prepare time slot on following day therefore patient can obtain queuing number and calculate estimated scheduled time for treatment.

d. Queue Management

Administrator have feature to inspect patient list on specific date and time. Administration officer can update the queue status after a patient already had medical treatment, patient not show up as scheduled (delaying), or patient confirming cancellation during scheduled time slot. This features offers possibility to readjust queue number to the next day because on one another reason. Transferring schedule will notify all affected patient.

e. Medical Records

Following features will be used by Doctor: 1) input patient medical checkup and other treatment data (including medical prescription) applied to patient. 2) Searching on patient data with advanced search method. 3) Visualization of tooth structure gives detailed information with better presentation that can be utilized by Doctor to deliver explanation to patient.

System requirements for patient are:

a. Patient Data Management

Handle patient registration and updating patient data within application.

b. Online Queue Registration and Cancellation.

This feature assist patient to obtain queue number and calculate treatment time estimation within same day. Additionally system has features to calculate treatment cost and patient could cancel their appointment using mobile application. Prior to cancellation, system automatically will issue notification to all subsequent patients and recalculate treatment time estimation. Therefore all patients will notice the update from mobile application.

c. Queuing Monitoring

Patient can manage to observe queue status including current administered patient status and administer time estimation for each number.

All requirements based on Dentist obligations and will be applied as groundwork for developing web based and mobile application. The intention of web based version is refined for internal use, whereas the mobile version is specifically developed for patient. In Figure 3, denotes the example of patient registration page accessible within mobile app. Authorized patient could utilizes Online Queue Registration feature to be placed on queue for medical treatment on selected date (Figure 4). Furthermore as denoted in Figure 5, patient could observe the queue status from Queuing Monitoring feature.

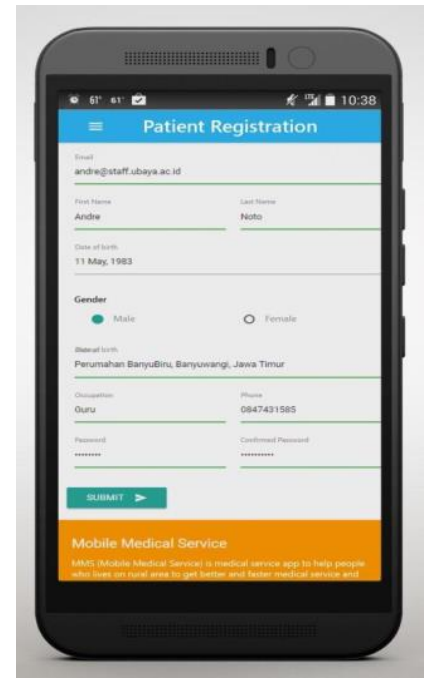

Figure 3. Patient registration form

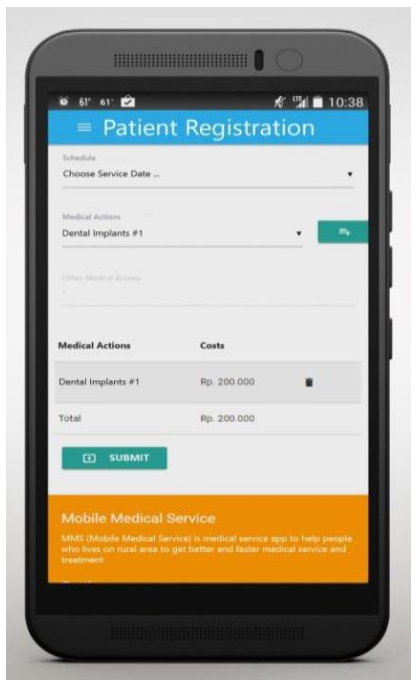

Figure 4. Patient registration page

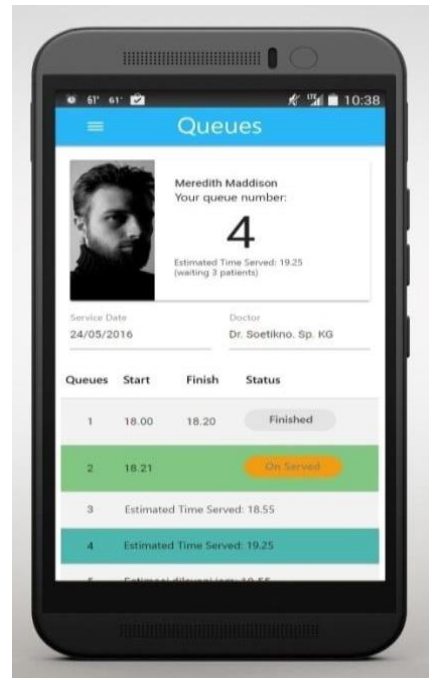

Figure 5. Queue monitoring page 
In Figure 6, designates medical records page that could be utilize by Doctor to commit examination and treatment result on particular patient. Patient teeth structure visualization projected to assisting Dentist when describing teeth conditions to the patient. In addition, administration officer could adjust patient queue status afterwards the patient treatment finished. Therefore all subsequent waiting patients on queue manage observing queue status on real time. Queue management page defined on Figure 7.

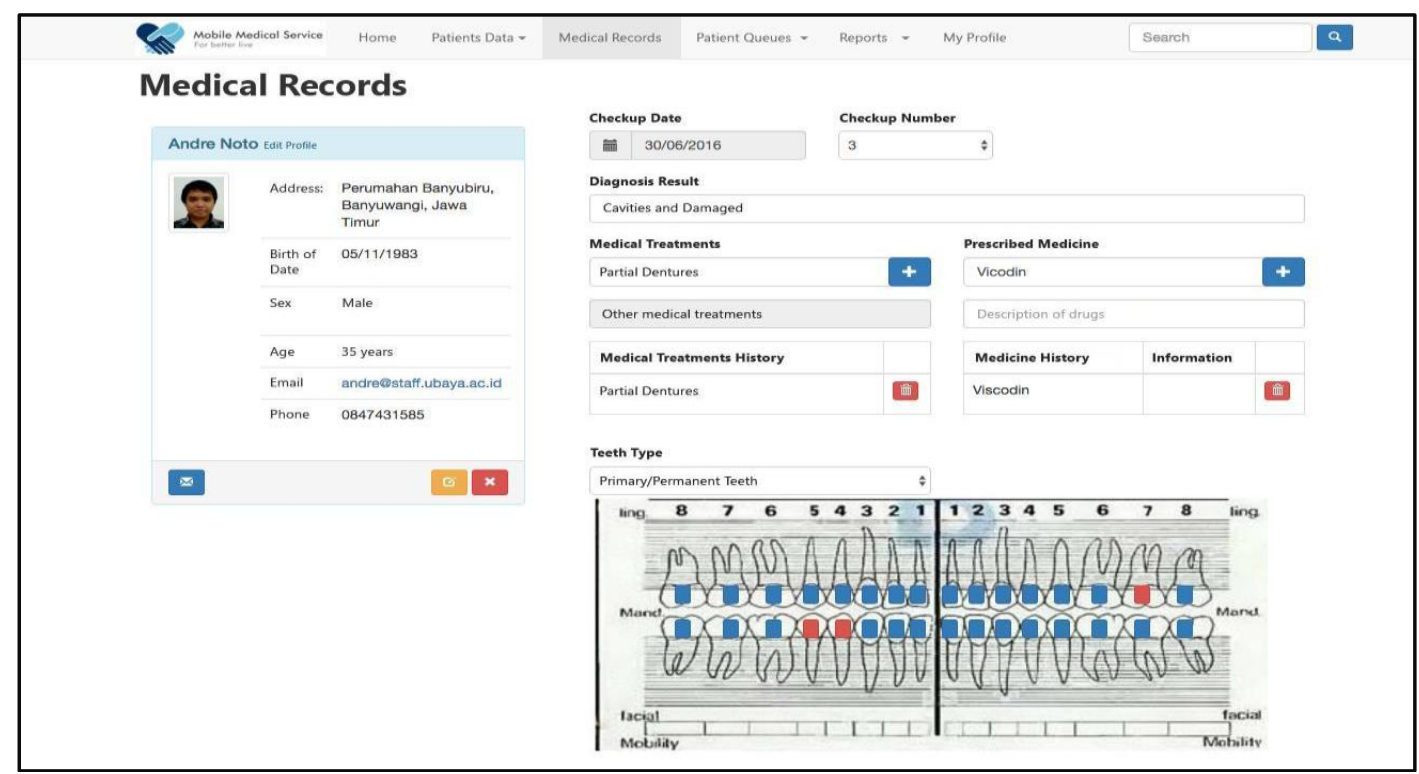

Figure 6. Medical records of patient

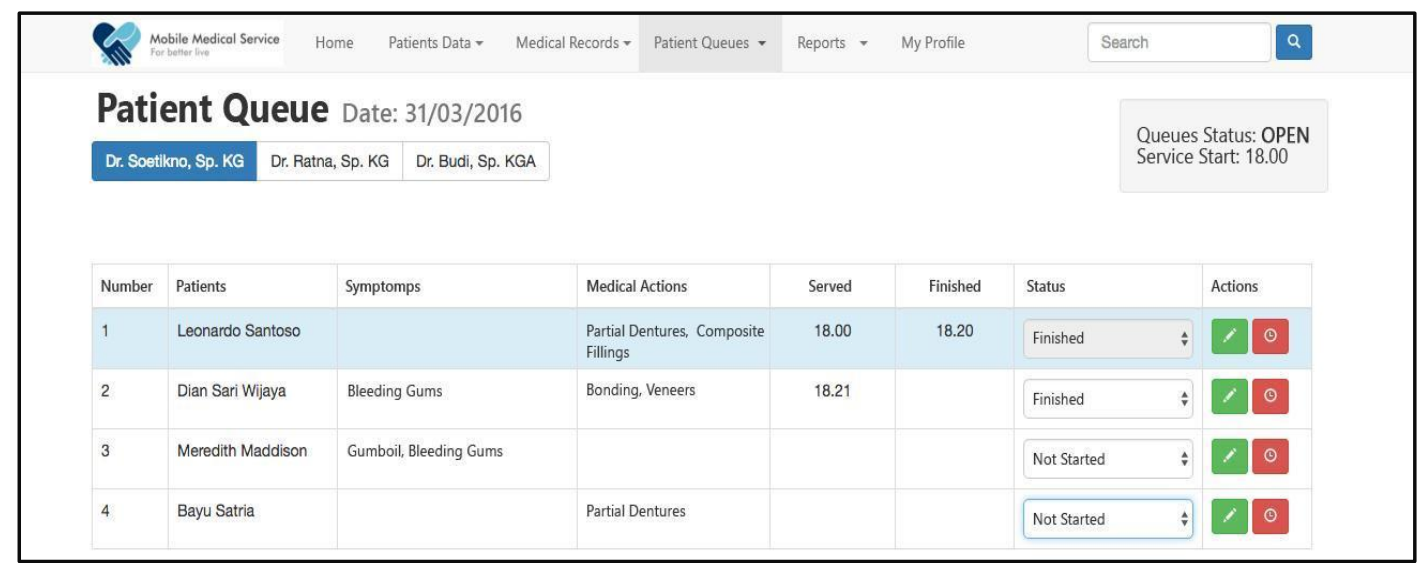

Figure 7. Queuing management page

Validation results performed by the dentist and administer on the application can be seen in Table 1 and the validation results performed by the patient can be seen in Table 2. Based on the result in Table 1, reveal that application strongly alleviating Dentist and administrator officer tasks in order to deliver better service for patient. Furthermore, based on patient validation on Table 2 indicate that the application robustly increase efficiency on time, cost, and energy. These validation results strengthen the research result conducted by Payne and Chaudhry ([23], [35]). One of ten patients expressing uncertainty regarding the capability of this application to calculates treatment time estimation accurately, specifically determining when patient have to come to the Doctor office. The possibility of this concern is this patient settle on rural area that has limited internet connection. Therefore the patient has difficulty to do basic thing like internet browsing and in this case operating the application features such as queue monitoring. 
Table 1. Dentist Validation Result

\begin{tabular}{|c|c|c|c|c|c|c|}
\hline No & Questions & $\begin{array}{l}\text { Strongly } \\
\text { Agree }\end{array}$ & Agree & Uncertain & Disagree & $\begin{array}{l}\text { Strongly } \\
\text { Disagree }\end{array}$ \\
\hline 1 & $\begin{array}{l}\text { Initialization process (office hours setting up) } \\
\text { works well as requirement }\end{array}$ & & $\checkmark$ & & & \\
\hline 2 & $\begin{array}{l}\text { Initialization process for following features: } \\
\text { treatment type, symptom, estimated time for each } \\
\text { symptom, and medical treatment. Overall process } \\
\text { beneficially assisted administration officer to } \\
\text { organize patient. }\end{array}$ & $\checkmark$ & & & & \\
\hline 3 & $\begin{array}{l}\text { Patient data management stimulate accessibility to } \\
\text { search for specific patient data }\end{array}$ & $\checkmark$ & & & & \\
\hline 4 & $\begin{array}{l}\text { Queue management facilitate administration officer } \\
\text { on patient handling }\end{array}$ & $\checkmark$ & & & & \\
\hline 5 & $\begin{array}{l}\text { Medical records management simplify searching } \\
\text { process for patient dental health records }\end{array}$ & $\checkmark$ & & & & \\
\hline
\end{tabular}

Table 2. Patient Validation Results

\begin{tabular}{|c|c|c|c|c|c|c|}
\hline \multirow[b]{2}{*}{ No } & \multirow[b]{2}{*}{ Questions } & \multicolumn{5}{|c|}{ Number of Patients } \\
\hline & & $\begin{array}{c}\text { Strongly } \\
\text { Agree }\end{array}$ & Agree & Uncertain & Disagree & $\begin{array}{l}\text { Strongly } \\
\text { Disagree }\end{array}$ \\
\hline 1 & $\begin{array}{l}\text { Patient data management alleviate } \\
\text { registration process }\end{array}$ & 4 & 6 & 0 & 0 & 0 \\
\hline 2 & $\begin{array}{l}\text { Simplify process of appointment request } \\
\text { by using online registration }\end{array}$ & 4 & 6 & 0 & 0 & 0 \\
\hline 3 & $\begin{array}{l}\text { Simplify process of cancelling any } \\
\text { appointment }\end{array}$ & 4 & 6 & 0 & 0 & 0 \\
\hline 4 & $\begin{array}{l}\text { Queue monitoring streamline patient } \\
\text { schedule and help patient predict in what } \\
\text { time they must depart to visit the Doctor }\end{array}$ & 2 & 7 & 1 & 0 & 0 \\
\hline
\end{tabular}

\section{CONCLUSION}

Medical Information System and Patient Queue Management Services have been developed to enhance services quality and efficiency especially for people who lived far from clinic/hospital. Application provides services for patient to register and controlling queue using smart phone on real time based. Therefore patient waiting time greatly reduced since they are able to predict when they should arrive at Doctor' office accurately. Any office schedule amendment broadcasted via SMS automatically by system to all patients on queue. Developed application contributed significantly for used by Doctor in searching patient medical record, therefore Doctor can deliver optimal medical treatment to patient. In conclusions the application has been proved to increase time, cost, and energy efficiency in the region with reliable and stable internet connection.

\section{REFERENCES}

[1] J. Lee, et al., "Body Information Analysis Based Personal Exercise Management System," International Journal of Electrical and Computer Engineering (IJECE), vol/issue: 8(2), pp. 422-432, 2018.

[2] D. K. Pambudi, "Keep Healthy On Old Age," Jurnal Olahraga Prestasi, vol/issue: 11(2), pp. 19-30, 2015.

[3] Suharjana, "Live Healthy Habit dan Character Education Value," Jurnal Pendidikan Karakter, vol/issue: 2(2), pp. 189-201, 2012.

[4] K. Mohammad, "Indonesia is Still Short of Doctors," Mutu Pelayanan Kesehatan, 2013. https://mutupelayanankesehatan.net/index.php/berita/290-indonesia-masih-kekurangan-dokter.

[5] L. K, Anna, "Number of Doctors in Indonesia enough, but Piling up in Big City," Kompas Health, 2016. http://health.kompas.com/read/2016/05/10/093908423/Jumlah.Dokter.di.Indonesia.Cukup.Tapi.Menumpuk.di.Kota .Besar.

[6] Y. Ilyas, "Determinant Distribution of Specialist Doctors in the City / District of Indonesia," Jurnal Manajemen Pelayanan Kesehatan, vol/issue: 09(03), pp. 146-155, 2006.

[7] D. C. A. Nugraha and I. Aknuranda, "An Overview of e-Health in Indonesia: Past and Present Applications," International Journal of Electrical and Computer Engineering (IJECE), vol/issue: 7(5), pp. 2441-2450, 2017.

[8] Z. Jidin, et al., "Arduino Based Paperless Queue Management System," TELKOMNIKA Telecommunication Computing Electronics and Control, vol/issue: 14(3), pp. 839-845, 2016.

[9] D. Madhavi and B. V. Ramana, "De-Identified Personal Health Care System Using Hadoop," International Journal of Electrical and Computer Engineering (IJECE), vol/issue: 5(6), pp. 1492-1499, 2015. 
[10] T. Prayoga and J. Abraham, "Behavioral Intention to Use IoT Health Device: The Role of Perceived Usefulness, Facilitated Appropriation, Big Five Personality Traits, and Cultural Value Orientations," International Journal of Electrical and Computer Engineering (IJECE), vol/issue: 6(4), pp. 1751-1765, 2016.

[11] O. Boyinbode and G. Toriola, "CloudeMR: A Cloud Based Electronic Medical Record System," International Journal of Hybrid Information Technology, vol/issue: 8(4), pp. 201-212, 2015.

[12] M. Taufik and H. D. Wahyuningsih, "Web Based Doctor Service Information System," Jurnal Ilmiah Go Infotech, vol/issue: 21(1), pp. 18-24, 2015

[13] Y. Budiono and H. B. Santoso, "Web Based Information System Dental Clinic on Case Study: Lotus Dental Care," Jurnal EKSIS, vol/issue: 09(01), pp. 13-19, 2016.

[14] D. J. Surjawan and A. Utama, "Web Based Medical Record Data Management with Case Study Puskesmas X," Jurnal Sistem Informasi, vol/issue: 8(1), pp. 29-40, 2013.

[15] J. Sundari. "Web Based Puskesmas Service Information System," Indonesian Journal on Software Engineering, vol/issue: 2(1), pp. 44-49, 2016.

[16] S. Nisar and A. B. Said, "Conceptual Model for Electronic Clinical Record Information System," International Journal of Information Sciences and Techniques (IJIST), vol/issue: 2(1), pp. 15-25, 2012.

[17] U. A. Faruq, "Designing Medical Record Application of Polyclinic Universitas Trilogi," Jurnal Informatika, vol/issue: 9(1), pp. 1017-1027, 2015.

[18] A. Marques, et al., "Medical Records System Adoption in European Hospitals," The Electronic Journal Information Systems Evaluation, vol/issue: 14(1), pp. 89-99, 2011.

[19] P. L. Côrtes and E. G. de P. Côrtes, "Hospital Information Systems: A Study of Electronic Patient Records," Journal of Information Systems and Technology Management, vol/issue: 8(1), 2011.

[20] T. D. Nguyen, et al., "A Web-Based Electronic Medical Records and Hospital Information System for Developing Countries," Journal of Health Informatics in Developing Countries, vol/issue: 5(1), pp. 155-170, 2011.

[21] F. Saad, et al., "Development of Graphical User Interface (GUI) for University Student Health Monitoring," Indonesian Journal of Electrical Engineering and Computer Science, vol/issue: 9(3), pp. 673-679, 2018.

[22] A. Jamal, et al., "The Impact of Health Information Technology on the Quality of Medical and Health Care: A Systematic Review," Health Information Management Journal, vol/issue: 38(3), pp 26-37, 2009.

[23] B. Chaudhry, et al., "Impact of Health Information Technology on Quality, Efficiency, and Costs.Annals of Internal Medicine," Annals of Internal Medicine, vol/issue: 144(10), pp. 742-52, 2006.

[24] S. Hameed, et al.., "An Efficient Emergency, Healthcare, and Medical Information System," International Journals of Biometric and Bioinformatics (IJBB), Kuala Lumpur, Malaysia, vol/issue: 2(5), pp. 1-9, 2011.

[25] M. Lavanya and M. U. Rani, "An Efficient Emergency, Healthcare, and Medical Information System," Global Journal of Computer Science and Technology Network, Web \& Security, vol/issue: 12(12), pp. 22-29, 2012.

[26] J. A. Milstein, "Health Care Requires Big Changes to Complement New IT," Harvard Business Review Journal, vol/issue: 87(4), pp. 20, 2009.

[27] APJII, "Survei Internet APJII," 2016. https://apjii.or.id/content/read/39/264/Survei-Internet-APJII-2016.

[28] Sukma D., "9 Out of 10 Indonesian People Using Smartphone to Browse Internet," 2016. https://arenalte.com/berita/industri/data-gfk-terbaru-2016-pengguna-smartphone-indonesia/.

[29] C. L. Ventola, "Mobile Devices and Apps for Health Care Professionals: Uses and Benefits," vol/issue: 39(5), pp. 356-364, 2014. https://www.ncbi.nlm.nih.gov/pmc/articles/PMC4029126/.

[30] D. Speidel and M. Sridharan, "Quality Assurance in the Age of Mobile Healthcare," The Journal of $m$ Health, vol/issue: 01(02), pp. 42-46, 2014.

[31] Ozdalga E., et al., "The Smartphone in Medicine: A Review of Current and Potential Use among Physicians and Students," Journal of Medical Internet Research, vol/issue: 14(5), pp. e128, 2012.

[32] Aungst T. D., "Medical Applications for Pharmacists using Mobile Devices," Ann Pharmacother, vol/issue: 47(78), pp. 1088-95, 2013.

[33] O’Neill K. M., et al., "Applying Surgical Apps: Smartphone and Tablet Apps Prove Useful in Clinical Practice," Bulletin of the American College of Surgeons, vol/issue: 98(11), pp. 10-18, 2013.

[34] Murfin M., "Know your Apps: An Evidence-Based Approach to the Evaluation of Mobile Clinical Applications," The Journal of Physician Assistant Education, vol/issue: 24(3), pp. 38-40, 2013.

[35] Payne K. B., et al., "Smartphone and Medical Related App Use among Medical Students and Junior Doctors in the United Kingdom (UK): A Regional Survey,” BMC Medical Informatics and Decision Making, vol. 12, pp. 121, 2012.

[36] J. R. Mohammed, "Low Complexity Adaptive Noise Canceller for Mobile Phones Based Remote Health Monitoring," International Journal of Electrical and Computer Engineering (IJECE), vol/issue: 4(3), pp. 422-432, 2014.

[37] David, et al., "Study of Relationship between Patient Satisfaction and Doctor Arrival Delay in Clinic," Jurnal Kedokteran Brawijaya, vol/issue: 28(1), pp. 31-35, 2014. 


\section{BIOGRAPHIES OF AUTHORS}

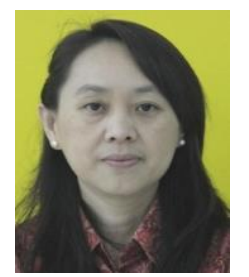

Susana Limanto actively works as lecturer in Informatics Department of Surabaya University. She began teaching in 1995 after completing undergraduate program in Informatics Degree in Surabaya University. In 2003, she take graduate program on statistics in ITS for 2 years with Thesis subject: Clustering Data Market Basket. She had expertise on Information System and Optimization. Several of her research already been published nationally or internationally such as: Improving Medical Service of Kindergarten School using Information Technology and Communication (Government Research Grant 2014-2015), Information System Analysis on Counseling Service in Multi-level School, and Supporting System to Help Customer Choose Tablet Based on Many Criteria.

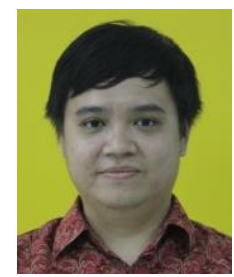

Andre has a M.Sc. in Digital Media Technology from Nanyang Technological University of Singapore. He currently serves as full time lecturer in Surabaya University (Ubaya) since 2008. $\mathrm{He}$ is the winner of the 'APICTA' award 2007 (Asia Pacific ICT Alliance) on student project category. Her recent publications include Smart class Scheduling on University Timetable (2016) and the Decision Tools for Purchasing Used Vehicle. 